\title{
Insulin-like growth factor (IgF)-I, IgF binding protein-3, and prostate cancer: correlation with gleason score
}

Lívia L. Corrêa ${ }^{1,3}$, Leonardo Vieira Neto ${ }^{1,4}$, Giovanna A. Balarini Lima ${ }^{1,5}$, Rafael Gabrich², Luiz Carlos D. de Miranda², Mônica R. Gadelha

${ }^{1}$ Endocrinology Service, University Hospital Clementino Fraga Filho (HUCFF), Universidade Federal do Rio de Janeiro, RJ, Brazil; ${ }^{2}$ Urology Service, University Hospital Clementino Fraga Filho (HUCFF), Universidade Federal do Rio de Janeiro (UFRJ), Rio de Janeiro, RJ, Brazil; ${ }^{3}$ Instituto Estadual de Diabetes e Endocrinologia Luiz Capriglione (IEDE), Rio de Janeiro, RJ, Brazil; ${ }^{4}$ Endocrinology Service, Hospital Federal da Lagoa, Rio de Janeiro, RJ, Brazil; ${ }^{5}$ Endocrinology Service, University Hospital Antônio Pedro (HUAP), Universidade Federal Fluminense (UFF), Niterói, RJ, Brazil

\section{ABSTRACT}

Introduction: Non-androgenic growth factors are involved in the growth regulation of prostate cancer $(\mathrm{PCa})$.

Objective: This is the first Brazilian study to correlate, in a population of patients operated for PCa, PSA, total testosterone, insulin-like growth factor-I (IGF-I) and insulin-like growth factor-binding protein-3 (IGFBP-3) with Gleason score and to compare with a control group with benign prostate hyperplasia (BPH).

Materials and Methods: This retrospective single-center study included 49 men with previously diagnosed PCa and 45 with previously diagnosed BPH. PSA, testosterone, IGF-I, IGFBP-3 were determined in both groups.

Results: PSA and IGFBP-3 levels were significantly higher in the PCa group as compared to the BPH group ( $\mathrm{p}<0.001$ and $\mathrm{p}=0.004$, respectively). There was a significant difference when we compared the PSA before surgery $(\mathrm{p}<0.001)$ and at the inclusion in the study $(\mathrm{p}<0.001)$ and IGFBP3 (0.016) among patients with Gleason $<7, \geq 7$ and $\mathrm{BPH}$. In the PCa group, PSA, testosterone, IGF-I and IGFBP-3 levels were comparable between Gleason $<7$ and $\geq 7$. Conclusions: Our data suggest that in localized PCa, the quantification of PSA and, not of IGF-1, may provide independent significant information in the aggressiveness. IGFBP-3 could be a biochemical marker of disease control in PCa patients.

\section{ARTICLE INFO}

\section{Key words:}

Prostatic Neoplasms; Prostatic

Hyperplasia; Insulin-Like Growth

Factor I; Insulin-Like Growth

Factor Binding Protein 3

Int Braz J Urol. 2015; 41: 110-5

Submitted for publication:

November 19, 2013

Accepted after revision:

June 23, 2014

\section{INTRODUCTION}

After non-melanoma skin cancer, prostate cancer ( $\mathrm{PCa}$ ) represents the most frequently diagnosed cancer in adult men with an annual incidence of approximately 50 cases per 100.000 men (1).

Androgens are considered the primary growth factors for prostate epithelial cells. However, other non-androgenic growth factors are involved in the growth regulation of PCa cells (2).

Insulin-like growth factor-I (IGF-I) is a potent mitogen for normal and cancerous cells and exerts the mitogenic action by increasing DNA synthesis and by stimulating the cell cycle progression (3). In addition, IGF-I also inhibits apoptosis (4). IGF-I has direct mitogenic and anti-apoptotic 
effects on normal and transformed prostate epithelial cells and has been implicated in the pathogenesis of $\mathrm{PCa}(5,6)$. The interaction between IGF-I and IGF-IR is regulated by the IGF-binding proteins (IGFBPs). Of the circulating binding proteins, IGFBP-3 is the most abundant one (7). At tissue level, IGFBP-3 regulates the mitogenic activity and inhibits the anti-apoptotic effect of IGF-I (8). Furthermore, IGFBP-3 has been linked to induction of apoptosis (9).

Several epidemiologic studies have suggested that high-normal serum IGF-I levels may be concordant with a higher risk of PCa $(5,10)$. It was observed a 38\% increased odds of prostate cancer risk comparing highest vs. lowest quintiles of IGF-I (11). The largest systematic review of studies reporting on the association of IGF-I with the risk of PCa was published in 2009 (12). It included both retrospective and prospective studies ( $\mathrm{n}=42$ studies) and demonstrated that the published literature is consistent with an average 21\% increase risk of PCa per standard deviation increase in IGF-I. They also showed a stronger association of IGF-I with more aggressive and advanced cancers. The probable inverse association between IGFBP-3 and PCa risk was only seen in retrospective, but not prospective studies.

A possible explanation for variability in normal IGF-I levels was proposed. Johansson et al. hypothesized that genetic variation in the 3' region of the IGF-I gene influences levels of circulating IGF-I and, therefore, PCa risk (13).

The prognosis of $\mathrm{PCa}$ is associated with Gleason score of the surgical specimen. It is considered a good prognosis if a Gleason score up to six (14). In 2005, the International Society of Urological Pathology (ISUP) modified the Gleason score system in order to get an accurate Gleason grade (15).

To date, in the Brazilian population, there is no study that correlates serum levels of IGF-I and IGFBP-3 with Gleason score in surgical specimens.

This study evaluated, in a population of patients operated for PCa, serum PSA, testosterone, IGF-I and IGFBP3 levels and correlated with Gleason score of the surgical specimens. All findings were compared with a control group with benign prostate hyperplasia (BPH).

\section{MATERIALS AND METHODS}

\section{Patients}

This retrospective single-center study included 49 men with previously diagnosed PCa and 45 men with previously diagnosed $\mathrm{BPH}$, recruited from the outpatient urology clinic. All PCa patients were submitted to radical prostatectomy from January 2007 to April 2010 and time elapsed between surgical intervention and inclusion in the study varied from 3-48 months. On the basis of the histological grade obtained at surgery, PCa patients were divided into two groups: Gleason score $<7$ and Gleason score $\geq 7$. This information was obtained from patient's records. The evaluation of prostatectomies specimens was done using the current grading system. All BPH patients were submitted to transurethral or suprapubic prostate resection at least five years before the inclusion in the study and presented with stable PSA values and digital rectal examination of the prostate without changes.

Reasons for ineligibility included patients with hepatic failure, uncontrolled diabetes mellitus, hypo or hyperthyroidism, GH deficiency, acromegaly, malnutrition and diseases that could interfere in serum levels of IGF-I and IGFBP-3. All subjects entered the study after obtaining written informed consent according to a protocol approved by the Ethics Committee.

\section{Clinical parameters}

All patients had the following data collected: age, preoperative serum PSA levels and type of surgery. For patients with PCa, Gleason score and complementary treatment were also documented.

\section{Hormone assays}

Serum IGF-I, IGFBP-3 and total testosterone levels were determined by chemiluminescense immunometric assays. Total PSA serum levels were measured by electrochemiluminescense assay before surgery - PSA 1 and at the inclusion in the study - PSA

The low detection limit of IGF-I measured by Immulite $2000 \mathrm{kit}$ DPC is $20 \mathrm{ng} / \mathrm{mL}$ and the 
intra and inter-assay CVs are 3.6 and 6.6\%, respectively. The standards are calibrated against the first International Reference Reagent WHO $87 / 518$ and IGF-I was expressed in mass units and age-related standard deviation scores (SD-scores). Group 0: -2 SD to zero and group 1: zero to +2 SD.

All serum samples were collected in the early morning after an eight-hour fasting period.

\section{Statistical analysis}

Analyses were performed by SPSS (version 16.0, SPSS, Inc., Chicago, IL). In the descriptive analysis, the categorical variables were expressed by their percentages and frequencies, whereas the numerical variables were expressed as mean \pm standard deviation (SD). The Mann-Whitney test was performed for comparison between two groups and the Kruskal-Wallis test was used to compare the numerical variables among three groups. Comparisons between categorical variables were done by $\chi^{2}$ test. The correlations between numeric variables were studied using the Spearman's correlation test. A p-value less than 0.05 was considered significant, except for comparisons between two of the three groups (PCa with Gleason $<7$, $\mathrm{PCa}$ with Gleason $\geq 7$ and $\mathrm{BPH}$ ), when $\mathrm{p}$-values $<0.017$ were considered significant (Bonferroni post hoc analysis).

\section{RESULTS}

\section{Patients' characteristics}

Ninety-four men entered this study: 49 (65.5 \pm 6.2 years-old, median 65) with previously diagnosed histologically confirmed prostate adenocarcinoma and 45 (66.8 \pm 8.0 years-old, median 67) with histologically confirmed BPH, without the finding of intraepithelial neoplasia. Clinical, laboratorial and pathological characteristics of the $\mathrm{PCa}$ and $\mathrm{BPH}$ cases are described in Table-1.

Considering the $\mathrm{PCa}$ patients, at the time of inclusion in the study, 28 had been submitted only to surgery, 10 had been submitted to surgery and radiotherapy and 11 had been submitted to surgery, radiotherapy and hormone therapy.

Comparison between PCa and BPH patients: Serum markers

Serum PSA (both before surgery and at the inclusion in the study) and IGFBP-3 levels were significantly higher in the PCa group as compared to the BPH group $(p<0.001 ; p<0.001$ and $p=0.004$, respectively) (Figures 1 and 2). Age, serum testosterone and IGF-I levels did not significantly differ between the two groups (Table-1). Categorizing IGF-I in SD-scores there was no statistically significant difference between the $\mathrm{PCa}$ and $\mathrm{BPH}$ groups.

A negative correlation was observed between PSA (both before surgery and at the inclusion in the study) and testosterone levels $(r=-0.36$,

Table 1 - Clinical, laboratorial and pathological characteristics of PCa and BPH patients.

\begin{tabular}{lccc}
\hline & PCa patients & BHP patients & p \\
\hline $\mathrm{n}$ & 49 & 45 & - \\
Age, years & $65.5 \pm 6.2$ & $66.8 \pm 8.0$ & 0.500 \\
$\mathrm{PSA}, \mathrm{ng} / \mathrm{mL}$ & $8.7 \pm 4.1$ & $3.6 \pm 1.7$ & $<\mathbf{0 . 0 0 1}$ \\
$\mathrm{PSA}_{2}, \mathrm{ng} / \mathrm{mL}$ & $0.2 \pm 0.4$ & $3.4 \pm 1.0$ & $<\mathbf{0 0 1}$ \\
Testosterone,ng/dL & $446.1 \pm 161.5$ & $542.3 \pm 144.3$ & 0.756 \\
IGF-I, $\mathrm{ng} / \mathrm{mL}$ & $126.8 \pm 42.0$ & $126.7 \pm 40.8$ & 0.976 \\
IGFBP3, $\mathrm{ng} / \mathrm{mL}$ & $3.5 \pm 0.8$ & $3.0 \pm 0.8$ & $\mathbf{0 . 0 0 4}$ \\
Gleason $<7$ & 26 & - & - \\
Gleason $\geq 7$ & 23 & - & - \\
\hline
\end{tabular}

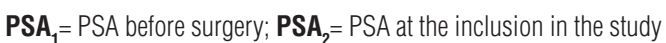


Figure 1 - Serum PSA levels (before surgery) in patients with prostatic hyperplasia and prostate cancer. Statistical significance was determined by Mann-Whitney's test. The lower and upper bars represent the first and third quartiles respectively. The line across the box represents median value. The lines above and below the box represent the highest and lowest values, excluding outliers.

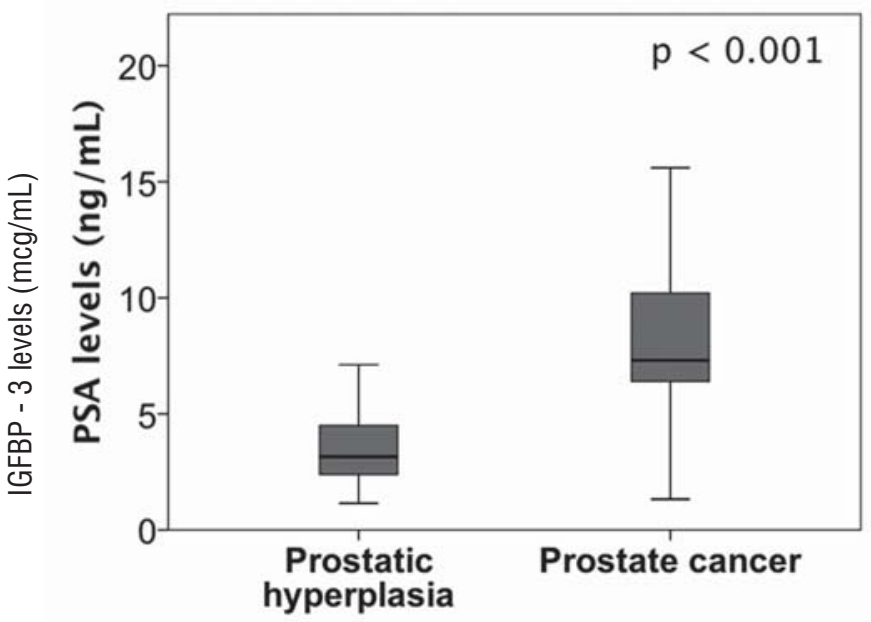

$\mathrm{p}=0.014$ and $\mathrm{r}=-0.43, \mathrm{p}=0.005$, respectively). A positive correlation was observed between IGFBP3 and testosterone levels $(\mathrm{r}=0.39, \mathrm{p}=0.008)$.

Age, serum markers and the Gleason score

In the PCa group, serum PSA, testosterone, IGF-I and IGFBP-3 levels were comparable between Gleason score $<7$ and Gleason $\geq 7$ cases (Table-2). Categorizing IGF-I in SD-scores (group $0:-2$ SD to zero and group 1: zero to $+2 \mathrm{SD}$ ) there
Figure 2 - Serum IGFBP-3 levels (at the inclusion in the study) in patients with prostatic hyperplasia and prostate cancer. Statistical significance was determined by MannWhitney's test. The lower and upper bars represent the first and third quartiles respectively. The line across the box represents median value. The lines above and below the box represent the highest and lowest values, excluding outliers.

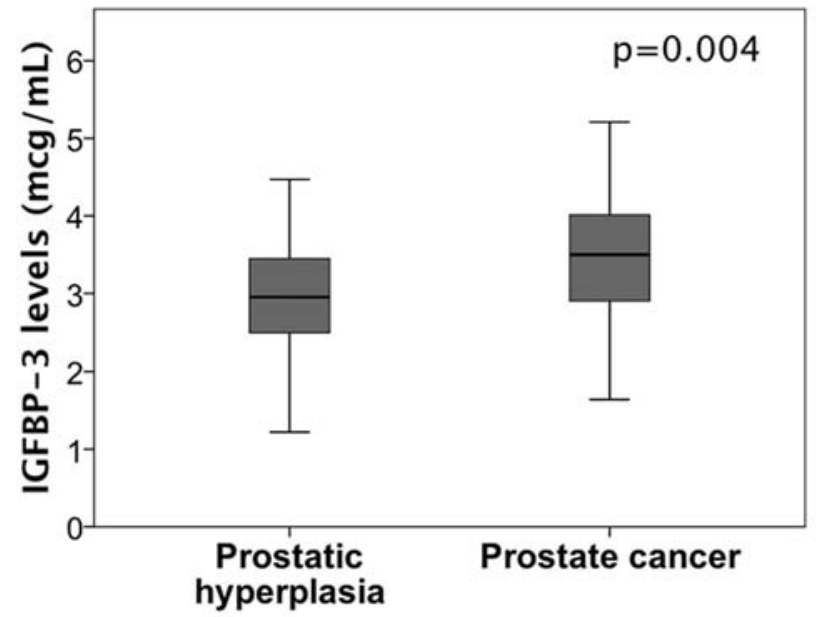

was no statistically significant difference between patients with Gleason score $<7$ and Gleason $\geq 7$. There was a significant difference when we compared the PSA levels before surgery $(\mathrm{p}<0.001)$ and at the inclusion in the study $(\mathrm{p}<0.001)$ and IGFBP3 levels (0.016) among patients with PCa Gleason $<7$, PCa Gleason $\geq 7$ and BPH. PSA levels (both before surgery and at the inclusion in the study) were higher in patients with PCa Gleason $<7$ and PCa Gleason $\geq 7$ ( $p<0.001$, both) than in those with

Table 2 - Clinical and laboratorial characteristics of PCa cases according to Gleason score.

\begin{tabular}{lccc}
\hline & Gleason $<7$ & Gleason $\geq 7$ & $p$ \\
\hline $\mathrm{n}$ & 26 & 23 & - \\
Age, years & $65.0 \pm 6.9$ & $66.0 \pm 5.2$ & 0.452 \\
$\mathrm{PSA}_{1}, \mathrm{ng} / \mathrm{mL}$ & $7.9 \pm 3.4$ & $9.6 \pm 4.8$ & 0.288 \\
$\mathrm{PSA}_{2}, \mathrm{ng} / \mathrm{mL}$ & $0.2 \pm 0.4$ & $0.3 \pm 0.4$ & 0.368 \\
Testosterone,ng/dL & $418.1 \pm 121.1$ & $477.7 \pm 195.6$ & 0.326 \\
IGF-I, ng/mL & $130.0 \pm 38.0$ & $123.1 \pm 46.7$ & 0.316 \\
IGFBP3, ng/mL & $3.4 \pm 0.8$ & $3.5 \pm 0.8$ & 0.833 \\
\hline
\end{tabular}

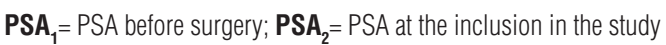


BPH. IGFBP3 levels were higher in patients with Gleason $\geq 7 \quad(p<0.016)$ than in those with BPH. There was no difference in PSA (both before surgery and at the inclusion in the study) and IGFBP3 levels between patients with PCa Gleason $<7$ and $\geq 7$. There was no difference in IGFBP3 levels between patients with $\mathrm{PCa}$ Gleason $<7$ and $\mathrm{BPH}$.

A negative correlation was observed between PSA at the inclusion in the study and testosterone levels $(r=-0.30, p=0.04)$.

\section{DISCUSSION}

This study analyzed and compared the serum levels of PSA, IGF-I and IGFBP-3 as possible markers of $\mathrm{PCa}$, according to the aggressiveness of the tumor in terms of Gleason score. For this reason, we selected a population of previously diagnosed PCa, all our tumor cases had been submitted to radical prostatectomy. As a control group, we included patients with previously diagnosed $\mathrm{BPH}$, all of them submitted to transurethral or suprapubic prostate resection at least five years before the inclusion in the study and with stable disease. We consider that this group of BPH patients represents a reliable sample of patients without PCa.

In our population, only serum PSA and IGFBP-3 levels, not IGF-I, were significantly higher in the PCa group than in the BPH group. A possible explanation for this was that the IGF-1 was assessed only after surgery. Marszalek et al. and Sciarra et al. $(16,17)$ did not find significant variations in IGF-I levels between PCa and control cases. Differently to our study, they did not evaluate IGFBP-3 levels and Marszalek et al. (16) did not have the possibility to analyze the results in terms of the Gleason score of the surgical specimens. Since IGFBP-3 is a substrate for PSA, by proteolytically cleavage (18), PCa patients with undetectable PSA levels are expected to have higher IGFBP-3 levels. The inverse correlation between PSA and IGFBP-3 could make IGFBP-3 a possible biochemical marker of disease control in PCa patients.

There is a known variability in IGF and gene sequencing among race groups that can influence disease incidence (19). Brazil has a heterogenic population that can limit these results.
Recently, Schumacher et al. (20) conducted a comprehensive analysis, utilizing a resequencing and tagging single-nucleotide polymorphism (SNP). They have identified a novel IGF-I SNP, not associated with IGF-I blood levels, which showed preliminary evidence for association with PCa risk among Caucasians.

In this study, serum PSA, testosterone, IGF-I and IGFBP-3 levels were comparable between PCa cases with Gleason score $<7$ and Gleason $\geq 7$. These findings are consistent with previous studies that demonstrated no significant variations in PSA and IGF-I according to the tumor Gleason score (16-18). As in our population, Ismail et al. (21) also found no significant difference in IGFBP-3 levels between patients with Gleason score $<7$ and Gleason $\geq 7$. The negative findings of our study are in agreement with other series suggesting that IGF-I serum levels provide no significant information considering aggressiveness of PCa. Moreover, it differs from epidemiological studies that also showed a stronger association of IGF-I with more aggressive and advanced cancers (12).

\section{CONCLUSIONS}

This was the first Brazilian study that correlated serum levels of IGF-I and IGFBP-3 with Gleason score in surgical specimens.

Our data suggest that in clinically localized PCa, the quantification of PSA and, not of IGF-I, may provide independent significant information in the aggressiveness of PCa. IGFBP-3 could be a biochemical marker of disease control in PCa patients.

\section{CONFLICT OF INTEREST}

None declared.

\section{REFERENCES}

1. Instituto Nacional do Câncer (INCA). Ministério da Saúde, Brasil. Available from: http://www.inca.gov.br.

2. Cunha GR, Donjacour AA, Cooke PS, Mee S, Bigsby RM, Higgins SJ, et al. The endocrinology and developmental biology of the prostate. Endocr Rev. 1987;8:338-62. 
3. Qu BH, Karas M, Koval A, LeRoith D. Insulin receptor substrate-4 enhances insulin-like growth factor-l-induced cell proliferation. J Biol Chem. 1999;274:31179-84.

4. Párrizas M, Saltiel AR, LeRoith D. Insulin-like growth factor 1 inhibits apoptosis using the phosphatidylinositol 3'-kinase and mitogen-activated protein kinase pathways. J Biol Chem. 1997;272:154-61.

5. Chan JM, Stampfer MJ, Giovannucci E, Gann PH, Ma J, Wilkinson P, Hennekens $\mathrm{CH}$, et al. Plasma insulin-like growth factor-I and prostate cancer risk: a prospective study. Science. 1998;279:563-6.

6. Cox ME, Gleave ME, Zakikhani M, Bell RH, Piura E, Vickers $\mathrm{E}$, et al. Insulin receptor expression by human prostate cancers. Prostate. 2009;69:33-40.

7. Jones JI, Clemmons DR. Insulin-like growth factors and their binding proteins: biological actions. Endocr Rev. 1995;16:334.

8. Baxter RC, Butt AJ, Schedlich LJ, Martin JL. Antiproliferative and pro-apoptotic activities of insulin-like growth factorbinding protein-3. Growth Horm IGF Res. 2000;10(Suppl A):S10-1.

9. Rajah $R$, Valentinis $B$, Cohen P. Insulin-like growth factor (IGF)-binding protein-3 induces apoptosis and mediates the effects of transforming growth factor-beta1 on programmed cell death through a p53- and IGF-independent mechanism. J Biol Chem. 1997;272:12181-8.

10. Wolk A, Mantzoros CS, Andersson SO, Bergström R, Signorello LB, Lagiou $P$, et al. Insulin-like growth factor 1 and prostate cancer risk: a population-based, case-control study. J Natl Cancer Inst. 1998;90:911-5.

11. Roddam AW, Allen NE, Appleby P, Key TJ, Ferrucci L, Carter $\mathrm{HB}$, et al. Insulin-like growth factors, their binding proteins, and prostate cancer risk: analysis of individual patient data from 12 prospective studies. Ann Intern Med. 2008 Oct 7;149(7):461-71, W83-8.

12. Rowlands MA, Gunnell D, Harris R, Vatten LJ, Holly JM, Martin RM. Circulating insulin-like growth factor peptides and prostate cancer risk: a systematic review and metaanalysis. Int J Cancer. 2009;124:2416-29.

13. Johansson M, McKay JD, Wiklund F, Rinaldi S, Verheus M, van Gils $\mathrm{CH}$, et al. Implications for prostate cancer of insulinlike growth factor-I (IGF-I) genetic variation and circulating IGF-I levels. J Clin Endocrinol Metab. 2007;92:4820-6.
14. Coetzee LJ, Layfield LJ, Hars V, Paulson DF. Proliferative index determination in prostatic carcinoma tissue: is there any additional prognostic value greater than that of Gleason score, ploidy and pathological stage? J Urol. 1997;157:214-8.

15. Epstein JI, Allsbrook WC Jr, Amin MB, Egevad LL; ISUP Grading Committee. The 2005 International Society of Urological Pathology (ISUP) Consensus Conference on Gleason Grading of Prostatic Carcinoma. Am J Surg Pathol. 2005;29:1228-42.

16. Marszalek M, Wachter J, Ponholzer A, Leitha T, Rauchenwald M, Madersbacher S. Insulin-like growth factor 1, chromogranin $A$ and prostate specific antigen serum levels in prostate cancer patients and controls. Eur Urol. 2005;48:34-9.

17. Sciarra A, Gentile V, Monti S, Dattilo C, Autran Gomez A, Salciccia S, et al. Comparison of chromogranin A, insulin-like growth factor 1 and prostate-specific antigen serum markers in prostate adenocarcinoma and benign prostatic hyperplasia. Urol Int. 2008;80:68-73.

18. Cohen P, Peehl DM, Graves HC, Rosenfeld RG. Biological effects of prostate specific antigen as an insulin-like growth factor binding protein-3 protease. J Endocrinol. 1994;142:407-15.

19. McGreevy K, Hoel B, Lipsitz S, Bissada N, Hoel D. Racial and anthropometric differences in plasma levels of insulin-like growth factor I and insulin-like growth factor binding protein-3. Urology. 2005;66:587-92.

20. Schumacher FR, Cheng I, Freedman ML, Mucci L, Allen NE, Pollak MN. A comprehensive analysis of common IGF1, IGFBP1 and IGFBP3 genetic variation with prospective IGF-I and IGFBP-3 blood levels and prostate cancer risk among Caucasians. Hum Mol Genet. 2010;19:3089-101.

21. Ismail HA, Pollak M, Behlouli H, Tanguay S, Bégin LR, Aprikian AG. Serum insulin-like growth factor (IGF)-1 and IGF-binding protein-3 do not correlate with Gleason score or quantity of prostate cancer in biopsy samples. BJU Int. 2003;92:699-702.

Correspondence address:

Lívia Lugarinho Corrêa de Mello, MD General San Martin, 900 / 603 Rio de Janeiro, RJ, 22441-014, Brazil FAX: + $55213507-9711$ E-mail: livia.lugarinho@terra.com.br 